\title{
The Relationship Between Possible Self of the Social Studies and History Teacher Candidates and the Attitudes Towards Teaching Profession
}

\author{
Kamil Uygun ${ }^{1} \&$ Muhammet Avaroğulları ${ }^{2}$ \\ ${ }^{1}$ School of Education, Uşak University, Uşak, Turkey \\ ${ }^{2}$ School of Education, Muğla Sitkı Koçman University, Muğla, Turkey \\ Correspondence: Muhammet Avaroğulları, School of Education, Muğla Sitkı Koçman University, Muğla, 48100, \\ Turkey. E-mail: muhammet@mu.edu.tr
}

\author{
Received: October 12, $2019 \quad$ Accepted: December 15, $2019 \quad$ Online Published: March 9, 2020 \\ doi:10.5539/ies.v13n4p64 \\ URL: https://doi.org/10.5539/ies.v13n4p64
}

\begin{abstract}
This study was conducted to determine to what extent the attitudes of pre-service teachers of social studies and history towards the teaching profession may predict possible teacher selves. Participants of the research are senior social studies teacher candidates studying at a public university in the spring semester of 2018-2019 academic year and history teacher candidates registered in the pedagogical formation program. Relational survey model, one of the survey models, was used in the research. The data was collected through Teacher Candidates Possible Selves Questionnaire and Attitude Scale towards Teaching Profession. The data obtained from the study were analyzed by Independent samples $t$ test and simple linear regression analysis techniques. According to the results obtained from the research, there was no difference between the attitudes of social studies teacher candidates and history teacher candidates who received pedagogical formation education towards the teaching profession. While the department of teacher candidates was not effective on the expected teacher selves, it was determined that it was effective on the feared teacher selves. It has been understood that the attitude towards teaching profession is effective in predicting expected possible selves, but it is ineffective in predicting feared possible selves that are feared. Suggestions were made in line with the results obtained from the research.
\end{abstract}

Keywords: possible selves, attitudes, social studies education, history education, teacher candidates

\section{Introduction}

The concept of self is a very important concept in terms of sociology, psychology, philosophy, anthropology and similar social sciences as well as in terms of educational sciences. Although there is no definite definition of the self-concept, it is possible to say that it is the whole of a person's answers to the questions "who am I?" "What kind of a person am I?" and "What makes me different from other people?" Kaya (1997) defines self as "the sum of the opinions about the person's own personality, the way of human self-knowledge and evaluation" (p. 194).

There are various theories related to the concept of self. One of them is the Possible Selves Theory developed by Markus and Nurius (1986). The person's perceptions of himself include not only his beliefs about the current state of the self, but also ideas and expectations about various potential situations. This second aspect of self-related knowledge has been described in possible self-theory (Bak, 2015). According to Markus and Nurius (1986), there are three possible types of self: expected, hoped for and feared selves. The self that a person thinks he/she can achieve is his /her expected self. Hoped for self is the self that the person desires, and finally the feared self is the self that one fears the realization of it (Tatl1-Dalioğlu, 2016; Uygun \& Karalı, 2019).

Possible selves are ideal selves. The Possible selves theory helps to discover the professional selves of prospective teachers and teachers who have just started teaching (Markus \& Nurius, 1986; Uygun \& Karal, 2019). Self-characteristics of teachers affect their identity. The formation of a social, cultural, moral or professional identity is important for the teaching profession (Uygun, 2019).

The fact that the effect of attitude is very important in the context of being successful in teaching profession can be explained by the high number of studies on attitude in the related literature. Based on various definitions (Çayak, 2014), the concept of attitude towards the teaching profession can be defined as the emotions and thoughts in the 
mind that direct the candidate's behavior related to the profession. When the literature is analyzed, it can be seen that there are a wide range of studies examining the relationship between the attitudes of teachers or prospective teachers towards the teaching profession with different variables (Atalmış \& Köse, 2018).

The first reason for this study is the possibility of determining the quality of the education to be given in education faculties. The perceptions of prospective teachers about what kind of teachers they will become in the future are mostly related to how they perceive themselves today. Being aware of possible selves in the process of preparing for teaching career can be effective in increasing success in professional life. Therefore, knowing how pre-service teachers perceive themselves is extremely important for both teacher candidates and teacher educators in education faculties. One of the tools that can be used to reveal these perceptions is possible selves. Possible selves theory is related to how pre-service teachers see and define themselves. Revealing the potential selves of prospective teachers can provide important data in the organization of the curriculum. The second reason for carrying out this study is that studies about the possible selves of the Turkish teacher candidates are limited with especially with regard to social studies and history teacher candidates.

With this study, it is aimed to reveal the teacher identities that are likely to occur in social studies and history teacher candidates by using the "teacher candidates possible selves scale". In addition, the attitudes of prospective teachers towards the teaching profession will be determined. Possible selves and attitudes of teacher candidates will be examined with regard to gender, department, and the place teacher candidates live. Finally, it will be checked whether the attitude towards teaching profession is effective in predicting the potential selfies of teacher candidates. Therefore, the research questions of the study are as follows:

- Is there a difference between the attitudes of teacher candidates towards the teaching profession depending on gender?

- Is there a difference between the perceptions of possible selves of teacher candidates towards the teaching profession depending on gender?

- Is there a difference between the attitudes of teacher candidates towards the teaching profession depending on the department?

- Is there a difference between the perceptions of possible selves of teacher candidates towards the teaching profession depending on the department?

- Is there a difference between the attitudes of teacher candidates towards the teaching profession depending on the place they live?

- Is there a difference between the perceptions of possible selves of teacher candidates towards the teaching profession depending on the place they live?

- What is the power of the attitude towards the teaching profession to predict the possible selves of prospective teachers?

\section{Method}

The research was carried out with the relational survey model, which is one of the quantitative research methods. The processes related to the universe and sampling, data collection and data analysis are described below.

\subsection{Universe and Sampling}

Universe of the study consists of senior social studies and history teacher candidates studying in Turkey. However, since it is not possible to reach this universe, the accessible universe has been determined as teacher candidates studying at Muğla Sıtkı Koçman University. The study group was formed by the convenient sampling method. Social studies teacher candidates who took the course "Republic History 1" (47 person) and History teacher candidates who took the course "Special Teaching Methods" (32 person) participated in the study. Teacher candidates enrolled in both programs took the methods courses. However, social studies teacher candidates also took the school experience lesson which requires them to visit schools each week for a semester.

\subsection{Data Collection}

Two separate scales were used to collect the data. The first of these scales is Prospective Teachers' Possible Self Scale, developed by Hammen, Wang, and Burley (2013) and adapted to Turkish by Tatl1-Dalioğlu and Adıgüzel (2015). There are two sub-dimensions in the scale: "Expected Possible Teacher Selves" and "Feared Possible Teacher Selves". The first dimension has two sub-dimensions, "professionalism" and "learning to teach". The second dimension has three sub-dimensions: "non-creative teaching", "inadequate classroom management" and "being an uninterested teacher". Cronbach Alpha internal consistency coefficients determined by Tatl1-Dalioğlu 
and Adıgüzel (2015) and in the present study are presented below.

Table 1. Cronbach Alpha internal consistency coefficients

\begin{tabular}{lcc}
\hline & Tatl-Dalioğlu ve Adı̈̈zel (2015) & Present study \\
\hline Professionalism & .79 & .71 \\
Learning to teach & .68 & .66 \\
Non-creative teaching & .86 & .84 \\
Inadequate classroom management & .81 & .85 \\
Being an uninterested teacher & .76 & .76 \\
\hline
\end{tabular}

From the examination of Table 1, it is understood that the values determined in the study of Tatl1-Dalioğlu and Adıgüzel (2015) and the values determined in this study are at similar and acceptable levels.

The second scale used in the research is the Attitude Scale towards Teaching Profession developed by Kahramanoğlu, Yokuş, Cışık, Vural, and Şiraz (2018). The scale is one-dimensional. Kahramanoğlu et al. (2018) specifies the Cronbach Alpha internal consistency coefficient as 85. In this study, Cronbach Alpha value was found to be .74 which is at an acceptable level.

\subsection{Analysis of the Data}

In order to determine which tests to use in the analysis of the data, a normality test was performed first. Whether the data obtained is normally distributed according to the variables of gender, residential area and education section was examined. As a result of the tests, it was understood that the data were not normally distributed, but the skewness and kurtosis values were between -2.00 and +2.00 . In this case, it has been understood that it is within acceptable value ranges for the application of parametric tests (George \& Mallery, 2003). Therefore, it was decided to apply parametric tests. Independent samples t-test was carried out to find out whether there is a difference between the attitudes towards the teacher profession and the average values of perceived possible selves of the teacher candidates in terms of gender, place of residence and department. In order to understand how much the attitude towards teaching profession can explain the perceived possible self, simple linear regression analysis was performed.

\section{Results}

The average values of prospective teachers about their expected and feared selves and their attitudes towards teaching profession were examined and the findings are presented in Table 2.

Table 2. Descriptive statistics about prospective teachers' possible selves perception and attitude towards teaching profession

\begin{tabular}{lccc}
\hline & $\mathrm{N}$ & $\bar{x}$ & $\mathrm{Ss}$ \\
\hline Expected Possible Selves & 79 & 5.34 & .45 \\
Professionalism & 79 & 5.43 & .46 \\
Learning to teach & 79 & 5.22 & .58 \\
Feared Possible Selves & 79 & 2.69 & 1.10 \\
Non-creative teaching & 79 & 2.57 & 1.35 \\
Inadequate classroom management & 79 & 3.14 & 1.33 \\
Being an uninterested teacher & 79 & 2.37 & 1.24 \\
Attitude towards teaching profession & 79 & 4.25 & .43 \\
\hline
\end{tabular}

According to Table 2, prospective teachers' perceptions of possible teacher selves indicate a value between "I am expecting" and "I am definitely expecting" and it is quite high. The perceptions of feared possible teacher selves correspond to the intervals of "I am not afraid" and "I am not afraid in part". The attitudes of prospective teachers towards the teaching profession also show a very high positive attitude.

\subsection{Findings Related to Gender}

Independent samples t-test was conducted to determine whether there is a difference between the values related to the attitude towards the teaching profession based on gender and the results are presented in Table 3. 
Table 3. Attitude towards teaching profession by gender

\begin{tabular}{|c|c|c|c|c|c|}
\hline Groups & $\mathrm{N}$ & $\bar{x}$ & SS & $\mathrm{t}$ & $\mathrm{p}$ \\
\hline Female & 47 & 4.33 & .43 & \multirow{2}{*}{1.97} & \multirow{2}{*}{.52} \\
\hline Male & 32 & 4.14 & .40 & & \\
\hline
\end{tabular}

According to these results, there was no statistically significant difference between female and male teacher candidates in terms of attitude towards teaching profession: $\mathrm{t}_{(77)}=-1.97, \mathrm{p}>.05$.

Independent samples t-test was conducted to find out whether there is a difference between the values regarding perception of expected possible teacher selves based on gender and the results are presented in Table 4.

Table 4. Expected possible teacher selves according to gender

\begin{tabular}{lcccccc}
\hline Sub-dimensions & Groups & $\mathrm{N}$ & $\bar{x}$ & $\mathrm{SS}$ & $\mathrm{t}$ & $\mathrm{p}$ \\
\hline \multirow{2}{*}{ Professionalism } & Female & 47 & 5.48 & .50 & \multirow{2}{*}{1.08} & \multirow{2}{*}{.283} \\
\cline { 2 - 6 } & Male & 32 & 5.36 & .41 & & \\
\hline \multirow{2}{*}{ Learning to teach } & Female & 47 & 5.14 & .65 & \multirow{2}{*}{-1.51} & \multirow{2}{*}{.134} \\
\cline { 2 - 6 } & Male & 32 & 5.33 & .43 & & \\
\hline
\end{tabular}

According to these results, it was understood that there was no statistically significant difference between the male teacher candidates and female teacher candidates in both sub-dimensions in terms of the perception of the expected teacher selves.

Independent samples t-test was conducted to find out whether there is a gender originated difference between the values related to the perceived feared possible teacher selves and the results are presented in Table 5.

Table 5. Feared possible teacher selves in terms of gender

\begin{tabular}{lcccccc}
\hline Alt boyutlar & Gruplar & $\mathrm{N}$ & $\bar{x}$ & $\mathrm{SS}$ & $\mathrm{t}$ & $\mathrm{p}$ \\
\hline \multirow{2}{*}{ Non-creative teaching } & Female & 47 & 2.68 & 1.35 & \multirow{2}{*}{.84} & \multirow{2}{*}{400} \\
\cline { 2 - 6 } & Male & 32 & 2.41 & 1.36 & & \\
\hline \multirow{2}{*}{ Inadequate classroom management } & Female & 47 & 3.35 & 1.34 & \multirow{2}{*}{1.68} & \multirow{2}{*}{.096} \\
\cline { 2 - 6 } & Male & 32 & 2.84 & 1.28 & & \\
\hline \multirow{2}{*}{ Being an uninterested teacher } & Female & 47 & 2.34 & 1.25 & \multirow{2}{*}{.224} & \multirow{2}{*}{.824} \\
\cline { 2 - 6 } & Male & 32 & 2.41 & 1.24 & & \\
\hline
\end{tabular}

According to these results, it was understood that there was no statistically significant difference between the male teacher candidates and the female teacher candidates in all three sub-dimensions in terms of the perception of feared possible selves.

\subsection{Findings about the Department}

Independent samples t-test was carried out to determine whether there is a difference between the values related to the attitude towards the teaching profession originating from the department where they study and the results are presented in Table 6.

Table 6. Attitude towards teaching profession by department

\begin{tabular}{|c|c|c|c|c|c|}
\hline Departments & $\mathrm{N}$ & $\bar{x}$ & SS & $\mathrm{t}$ & $\mathrm{p}$ \\
\hline Social studies & 47 & 4.28 & .42 & \multirow{2}{*}{.62} & \multirow{2}{*}{.533} \\
\hline History & 32 & 4.21 & .44 & & \\
\hline
\end{tabular}

According to these results, it was understood that there was no statistically significant difference between the social studies teacher candidates and the history teacher candidates in terms of attitude towards teaching profession: $\mathrm{t}_{(77)}=.62, \mathrm{p}>.05$.

Independent samples t-test was conducted to determine whether there is a difference between the values regarding the expected possible teacher selves and the results are presented in Table 7. 
Table 7. Expected possible teacher selves in terms of department

\begin{tabular}{lcccccc}
\hline Sub-dimensions & Groups & $\mathrm{N}$ & $\bar{x}$ & $\mathrm{SS}$ & $\mathrm{t}$ & $\mathrm{p}$ \\
\hline \multirow{2}{*}{ Professionalism } & Social studies & 47 & 5.49 & .46 & \multirow{2}{*}{1.28} & \multirow{2}{*}{.204} \\
\cline { 2 - 6 } & History & 32 & 5.35 & .47 & & \\
\hline \multirow{2}{*}{ Learning to teach } & Social studies & 47 & 5.25 & .53 & \multirow{2}{*}{.46} & \multirow{2}{*}{.643} \\
\cline { 2 - 5 } & History & 32 & 5.18 & .65 & & \\
\hline
\end{tabular}

According to these results, it was understood that there was no statistically significant difference between the social studies teacher candidates and the history teacher candidates in both sub-dimensions.

Independent groups t-test was carried out to determine whether there is a difference between the values related to the perceived feared possible teacher selves, and the results are presented in Table 8.

Table 8. Feared possible teacher selves according to the department

\begin{tabular}{llccccc}
\hline Sub dimensions & Groups & $\mathrm{N}$ & $\bar{x}$ & $\mathrm{SS}$ & $\mathrm{t}$ & $\mathrm{p}$ \\
\hline \multirow{2}{*}{ Non-creative teaching } & Social studies & 47 & 2.21 & .95 & \multirow{2}{*}{-2.64} & \multirow{2}{*}{.011} \\
\cline { 2 - 6 } & History & 32 & 3.09 & 1.67 & & \\
\hline \multirow{2}{*}{ Inadequate classroom management } & Social studies & 47 & 2.65 & .85 & \multirow{2}{*}{-4.02} & \multirow{2}{*}{.000} \\
\cline { 2 - 5 } & History & 32 & 3.87 & 1.57 & & \\
\hline \multirow{2}{*}{ Being an uninterested teacher } & Social studies & 47 & 2.10 & 1.07 & \multirow{2}{*}{-2.42} & \multirow{2}{*}{.018} \\
\cline { 2 - 5 } & History & 32 & 2.77 & 1.37 & & \\
\hline
\end{tabular}

According to these results, it has been understood that there is a significant difference between the teacher candidates in terms of feared possible teacher selves originating from the department they study. These differences appeared as $\mathrm{t}_{(77)}=-.2 .64, \mathrm{p}>.05$ in non-creative teaching sub-dimension; $\mathrm{t}_{(77)}=-.4 .02, \mathrm{p}>.05$ in the inadequate class management sub-dimension; $\mathrm{t}_{(77)}=-.2 .42, \mathrm{p}>.05$ In the sub-dimension of being an irrelevant teacher. Feared possible teacher selves perceptions of the prospective teachers studying in the history department are statistically significantly higher than that of the prospective teachers studying in the social studies education department.

\subsection{Findings about the Place of Residence}

Independent groups t-test was conducted to determine whether there is a difference between the values related to the attitude towards teaching profession that originates from place of residence, and the results are presented in Table 9.

Table 9. Attitude towards teaching profession by place of residence

\begin{tabular}{|c|c|c|c|c|c|}
\hline Groups & $\mathrm{N}$ & $\bar{x}$ & SS & $\mathrm{t}$ & $\mathrm{p}$ \\
\hline Rural & 22 & 4.42 & .34 & \multirow{2}{*}{2.23} & \multirow{2}{*}{.029} \\
\hline Urban & 57 & 4.19 & .44 & & \\
\hline
\end{tabular}

According to these results, it was understood that there was a statistically significant difference between teacher candidates living in rural areas and teacher candidates living in urban areas: $\mathrm{t}_{(77)}=2.23, \mathrm{p}<.05$.

Independent groups t-test was carried out to determine whether there is a difference between the values regarding the expected possible teacher selves, and the results are presented in Table 10.

Table 10. Expected possible teaching selves according to place of residence

\begin{tabular}{lcccccc}
\hline Sub-dimensions & Groups & $\mathrm{N}$ & $\bar{x}$ & $\mathrm{SS}$ & $\mathrm{t}$ & $\mathrm{p}$ \\
\hline \multirow{2}{*}{ Professionalism } & Rural & 22 & 5.50 & .53 & \multirow{2}{*}{.727} & \multirow{2}{*}{.469} \\
\cline { 2 - 6 } & Urban & 57 & 5.41 & .44 & & \\
\hline \multirow{2}{*}{ Learning to teach } & Rural & 22 & 5.28 & .62 & \multirow{2}{*}{.560} & \multirow{2}{*}{.577} \\
\cline { 2 - 5 } & Urban & 57 & 5.20 & .56 & & \\
\hline
\end{tabular}


According to these results, it was understood that there was no statistically significant difference in both sub-dimensions between teacher candidates living in rural areas and teacher candidates living in urban areas.

Independent groups t-test was carried out to determine whether there is a difference between the values related to the perceived feared possible teacher selves and the results are presented in Table 11.

Table 11. Feared possible teacher selves by place of residence

\begin{tabular}{lccccccc}
\hline Sub dimensions & Groups & $\mathrm{N}$ & $\overline{\mathrm{x}}$ & $\mathrm{SS}$ & $\mathrm{t}$ & $\mathrm{p}$ \\
\hline \multirow{2}{*}{ Non-creative teaching } & Rural & 22 & 2.28 & 1.25 & \multirow{2}{*}{-1.16} & \multirow{2}{*}{.248} \\
\cline { 2 - 6 } & Urban & 57 & 2.68 & 1.39 & & \\
\hline \multirow{2}{*}{ Inadequate classroom management } & Rural & 22 & 2.95 & 1.10 & \multirow{2}{*}{-.889} & \multirow{2}{*}{.378} \\
\cline { 2 - 6 } & Urban & 57 & 3.22 & 1.41 & & \\
\hline \multirow{2}{*}{ Being an uninterested teacher } & Rural & 22 & 2.37 & 1.17 & \multirow{2}{*}{-.010} & \multirow{2}{*}{.992} \\
\cline { 2 - 6 } & Urban & 57 & 2.37 & 1.27 & & \\
\hline
\end{tabular}

According to these results, it was understood that there was no statistically significant difference in all three sub-dimensions between pre-service teachers living in rural areas and pre-service teachers living in cities.

\subsection{Findings about the Effect of Attitude Towards Teaching Profession on the Possible Selves of Teacher Candidates}

In this section, findings regarding the effect of attitudes towards teaching profession on expected and feared teacher selves will be given.

3.4.1 The Effect of the Attitude Towards Teaching Profession on the Expected Possible Selves of Teacher Candidates

There are two sub-dimensions of the expected possible teacher self. These sub-dimensions are professionalism and learning to teach. The results of simple linear regression analysis regarding the predictive power of the attitude towards teaching profession on professionalism sub-dimension are presented in Table 12 and Table 13.

Table 12. The prediction level of attitude towards the teaching profession on the sub-dimensions of the expected possible teacher selves

\begin{tabular}{lcccc}
\hline & $\mathrm{R}$ & $\mathrm{R}^{2}$ & Adjusted $\mathrm{R}^{2}$ & Std. Error of the Estimate \\
\hline Professionalism & .477 & .228 & .218 & .41538 \\
Learning to teach & .413 & .170 & .159 & .53512 \\
\hline
\end{tabular}

According to Table 12, the attitudes of the participants of this study about the profession of teaching explain $22 \%$ of the total variance related to the professionalism sub-dimension of the expected teacher self and $17 \%$ of the total variance related to the learning to teach sub-dimension.

Table 13. Simple linear regression analysis coefficients table to determine the predictive state of attitude towards the teaching profession on the expected possible self

\begin{tabular}{lcccccc}
\hline Constant & Dependents & B & Standard Error & $\beta$ & $\mathrm{t}$ & $\mathrm{p}$ \\
\hline \multirow{2}{*}{ Attitude towards teaching profession } & Professionalism & .519 & .109 & .477 & 4.76 & .000 \\
& Learning to teach & .557 & .140 & .413 & 3.97 & .000 \\
\hline
\end{tabular}

According to Table 13, there is a positive (.519) relationship between the attitude towards the teaching profession and the professionalism sub-dimension of the expected possible teacher selves. This relationship seems to be meaningful $(\mathrm{t}=4.76, \mathrm{p}=0.000)$. There is a significant positive linear relationship between the attitude towards the teaching profession and the professionalism sub-dimension of the expected possible teacher selves. There is a positive (.557) relationship between the attitude towards the teaching profession and the learning to teach sub-dimension of the expected possible teacher selves. This relationship also seems to be meaningful $(\mathrm{t}=3.97$, $\mathrm{p}=0.000$ ). There is a significant positive linear relationship between the attitude towards teaching profession and the learning to teach sub-dimension of expected possible teacher selves. 


\subsubsection{The Effect of Attitude Towards Teaching Profession on Prospective Teachers' Feared Possible Selves}

There are three sub-dimensions of the feared possible teacher self. These sub-dimensions are fear of being an uncreative teacher, fear of being inadequate in classroom management and fear of being an uninterested teacher. The results of the simple linear regression analysis regarding the power of attitude towards the teaching profession on predicting these dimensions are presented in Table 14.

Table 14. The prediction power of attitude towards the teaching profession on the feared possible teacher self

\begin{tabular}{lcccc}
\hline & $\mathrm{R}$ & $\mathrm{R}^{2}$ & Adjusted $\mathrm{R}^{2}$ & Std. Error of the Estimate \\
\hline Non-creative teaching & .024 & .001 & -.012 & 1.36813 \\
Inadequate classroom management & .060 & .004 & -.009 & 1.34253 \\
Being an uninterested teacher & .058 & .003 & -.010 & 1.24631 \\
\hline
\end{tabular}

When Table 14 is examined, it is understood that the attitude towards the teaching profession does not have the power to predict the feared possible teaching selves.

\section{Discussion and Conclusion}

It is seen that prospective teachers 'perceptions of expected possible teacher selves are quite high while perceptions of feared selves are considerably low. This is in line with the results reported by Aktas (2019), Babanoglu and Agcam (2018), Çelik, Yorulmaz, and Çokçalışkan (2019), Tavsanli and Sarac (2016), Karali (2018), and Uygun and Karali (2019). The highly positive attitude towards the teaching profession is also in line with the results reported in the literature.

It is understood that there is no difference in terms of attitude towards teaching profession due to gender or education. It has been understood that the only variable that can make a significant difference between the values of pre-service teachers' attitudes towards teaching profession is the place where they live. These findings will be discussed below.

\subsection{Discussion of Findings Related to Gender Variable}

It was observed that gender, which is the first of the variables discussed in the study, has no effect on the perceptions of possible teacher selves teacher candidates. When the relevant literature is examined, it is seen that there are studies reporting gender as both an effective and ineffective factor. For example, Tavsanli and Sarac (2016) worked with pre-service classroom teachers and Uygun and Karali (2019) worked with social studies teacher candidates and both found that gender is an effective factor. According to Tavsanli and Sarac (2016), gender is effective on both sub-dimensions of expected possible teacher selves. Similarly, Uygun and Karali (2019) found that gender only makes a significant difference in terms of expected possible teacher selves. Göçer (2019) found that gender is effective on expected possible selves and on one dimension of feared possible selves. Aktaş (2019), on the other hand, did not find a significant difference in terms of expected possible teacher selves, but reported a significant difference in terms of feared possible teaching selves. On the contrary, Babanoğlu and A ğçam (2018) state that gender does not make any significant difference in any dimension. Considering the lack of a consistent result in other studies, another gender-related mediator variable can be considered to be effective.

No significant difference was observed in the attitude towards the teaching profession based on gender. However, in some previous studies on attitude towards teaching profession, a significant difference has been reported in favor of female students (Aksoy, 2010; Camadan \& Duysak, 2010; Dönmez \& Uslu, 2013; Gökçe \& Sezer, 2012; Karatekin, Merey, \& Keçe, 2015; Tay \& Akyürek-Tay, 2006; Terzi \& Tezci, 2007). However, there are also studies that do not report a significant difference (Bulut, 2009; Kartal \& Afacan, 2012). In this case, it can be thought that the effect of gender on attitude is not certain.

\subsection{Discussion of Findings Related to the Department Variable}

It was found out that the department was not effective on the expected possible teacher selves. However, it was observed that there was a significant difference originating from the department among the values related to the feared possible teacher selves. Feared possible teacher selves perception of Candidates studying in the history department is higher than those studying in the social studies department. The probable reason for this situation may be that prospective teachers in the social studies department take more courses about teaching and spend more time in schools. Perhaps the reason why the pre-service history teachers' fears are high is that they are separated from the K-12 environment for a long time. They have an extra concern before returning to the K-12 environment as a teacher. In addition, students of education faculty are getting more education to use various materials 
instructional methods (Dönmez \& Tangülü, 2012; Durmaz \& Kiriş-Avaroğulları, 2016; Gökdemir \& Gazel, 2019). Another reason may be anxiety levels of prospective teachers. As a matter of fact, in the study conducted by Sever, Aktaş, Şahin, and Tunca (2015), it was determined that prospective teachers enrolled in the pedagogical formation may encounter problems such as not being able to provide classroom management and not communicating effectively with students. The quality of pedagogic formation programs can also be important. In the study conducted by Demirtaş and Kırbaç (2016), it was reported that most of the students enrolled in the pedagogical formation certificate program found the pedagogical formation education inadequate due to the short program duration, the program was compressed, the time and conditions were not suitable, the teachers and the program were not efficient and the courses were not oriented towards implementation. In addition, Dündar and Karaca (2013) reported that most of the pedagogical formation students explained the pedagogical formation program with negative metaphors such as formation as a dark path and formation as a torture tool. There are also studies reporting that pedagogical formation students may lack of some basic instructional skills such as questioning (Kiriş-Avaroğulları \& Vurgun 2018) which may increase their concern. When the results of this study are evaluated together with other studies, it is understood why the pre-service teachers' fears are higher. However, an examination of the related literature reveals that conflicting results regarding the effect of the department are reported. Babanoğlu and Ağçam (2018), who examined prospective teachers from different departments, found differences in terms of expected possible selves while they did not find any difference in terms of feared possible feared selves. Similarly Göçer (2019) reported that there are meaningful differences among teacher candidates from different departments in terms of expected possible selves, yet such a difference occurs only with regard to one dimension of feared possible selves. However, one should keep in mind that prospective teachers participating in the study of Babanoğlu and Ağçam (2018), and Göçer (2019)) receive education in the Faculties of Education. Therefore, the fact that History candidates in our study are from the Faculty of Letters is perhaps the main source of the meaningful difference with regard to feared possible selves. Uygun and Karalı (2019) examined social studies teacher candidates from different universities reported a significant difference originating from the university in terms of both expected and feared teacher selves. Aktaş (2019), on the other hand, reports a difference only from the university where the teacher candidates study in terms of only feared possible selves. Thus it is hard to say that department variable itself alone makes a significant difference, but it is clear that it results in meaningful difference when it is coupled with some other variables which is unknown to us yet.

No significant difference was found among the values indicating the attitudes of prospective teachers towards the teaching profession, resulting from the department. Yet, the differences arising from the department are reported in the related literature (Bulut, 2009; Camadan \& Duysak, 2010; Gökçe \& Sezer, 2012; Kartal \& Afacan, 2013; Terzi $\&$ Tezci, 2007). The departmental differences mentioned in these studies are generally between the departments of social sciences and departments of science. The history and social studies departments examined in this study are very close to each other. Perhaps that is why there was no difference between the two departments in terms of the attitude towards teaching profession. However when we look at related literature about pedagogical formation students in general it is possible to see that There are studies reporting that the attitudes of pedagogical formation students towards the teaching profession are above the middle level (Kartal \& Afacan, 2012) and more positive (Bağçeci, Yıldırım, Kara, \& Keskinpalta, 2015) than the senior students of the education faculty. However, there is a difference between teacher candidates studying in the Faculty of Education and those who are registered in the Faculty of Literature and who have received a pedagogical formation certificate from the education faculty based on perception towards teaching profession (Özdemir, Tulumcu, \& Tulumcu, 2019) and the levels of self-efficacy and job satisfaction (Urbay-Şen, 2015). Teacher candidates in the Faculty of Education are more positive in those aspects according to relevant literature.

\subsection{Discussion of the Findings about the Place of Residence Variable}

In this study, it was revealed that there was no significant difference arising from the place of residence in terms of possible teacher selves perception. This situation confirms the work of Tavsanli and Sarac (2016) and Uygun and Karali (2019). However, it has been revealed that the place of residence is important in terms of attitude towards teaching profession. Accordingly, the pre-service teachers' attitudes towards the teaching profession, who spent most of their life in the countryside, are more positive. Accordingly, the pre-service teachers' attitudes towards the teaching profession, who spent most of their life in the countryside, are more positive. The probable reason for this is that teachers are perceived as a higher level profession in rural areas where there is less professional diversity and jobs based on physical strength are more common. However, in the related literature, there are opposite results. For example, Tay and Akyürek-Tay (2006) stated that the attitudes of those residing in the provincial centers are higher than those living in the villages. 


\subsection{Discussion of the Findings on the Predictive Effect of Attitudes Towards Teaching Profession on Possible Teacher Selves}

It is understood that the attitude towards the teaching profession explains $22 \%$ of the total variance in the professionalism dimension of the expected possible teacher selves and $17 \%$ of the total variance in the learning to teach dimension. Therefore, it can be said that attitude towards teaching profession is an important predictor of the expected possible teacher selves. Tatlı-Dalioğlu and Adıgüzel (2017) reported that their attitude towards teaching profession and self-efficacy beliefs of teacher candidates explain a total of $29 \%$ of the variance in expected possible teacher selves. However, they state that $22 \%$ of this variance is explained by only their self-efficacy beliefs. Therefore the finding that $22 \%$ of the total variance was explained by the attitude towards the teaching profession in this study is a striking one. However, it was understood that the attitude towards the teaching profession was not effective in predicting the feared possible self. Tatlı-Dalioğlu and Adıgüzel (2017) did not investigate the effect of the attitude towards the teaching profession on the feared possible self.

\subsection{Conclusion and Recommendations}

As a result, it was understood that gender did not affect prospective teachers' possible selves. Also, gender is not effective on attitude towards teaching profession. The department of teacher candidates is not effective on the expected possible teacher selves, but it is effective on the feared possible teacher selves. Students of the history department have higher fears. The fears of teacher candidates from the history department can be further investigated and changes can be made in the curriculum according to the findings. We believe that arrangements in the curriculum may solve many problems (Avaroğulları \& Ata, 2013). Perhaps a pedagogical formation program, which can be given for four years from the first year, may be an effective solution. The place of residence is also not an effective factor on possible teacher selves. However, it has an effect on the attitude towards the teaching profession. The attitudes of teacher candidates living in rural areas towards the teaching profession are significantly high. It is necessary to think about what can be done and develop solutions to further improve the attitudes of teacher candidates living in urban areas towards the teaching profession. It has been understood that the attitude towards teaching profession is effective in predicting possible selves, but it is ineffective in predicting feared possible selves.

\section{References}

Aksoy, M. A. (2010). Öğretmen adaylarının öğretmenlik mesleğine \& ilişkin tutumları (Gaziosmanpaşa üniversitesi örneği). Sosyal Bilimler Araştırmaları Dergisi, 2, 197-212. https://doi.org/10.19129/sbad.177

Aktaş, K. (2019). Ingilizce öğretmen adaylarının meslekteki ilk yıllarına yönelik olası benlikleri ile özel alan yeterlikleri arasindaki iliski (The relationship between the possible selves for the early years of english teacher candidates and their special field competencies) (Unpublished doctoral dissertation). Van Yüzüncü Y1l Üniversitesi, Eğitim Bilimleri Enstitüsü.

Atalmış, E. H., \& Köse, A. (2018). Turkish prospective teachers' attitudes towards the teaching profession: a meta analysis study. Journal of Measurement and Evaluation in Education and Psychology, 9(4), 393-413. https://doi.org/10.21031/epod.410287

Avaroğulları, M., \& Ata, B. (2013). Sosyal bilgiler öğretmeni adayları ve intihal: önbilgileri, intihalin yaygınlığı ve başvurulan yöntemler. Gaziosmanpaşa Bilimsel Araştırma Dergisi, 4, 94-107.

Babanoğlu, M. P., \& Ağçam, R. (2018). Exploring Possible-selves of Turkish Prospective Teachers. Akdeniz Egitim Arastirmalari Dergisi, 12(26), 447-462. https://doi.org/10.29329/mjer.2018.172.22

Bağçeci, B., Yıldırım, İ., Kara, K., \& Keskinpalta, D. (2015). Pedagojik formasyon ve eğitim fakültesi öğrencilerinin öğretmenlik mesleğine yönelik tutumlarının karşılaştırılması. Erzincan Eğitim Fakültesi Dergisi, 17(1), 307-324. https://doi.org/10.17556/jef.52416

Bak, W. (2015). Possible Selves: Implications for Psychotherapy. International Journal of Mental Health and Addiction, 13(5), 650-658. https://doi.org/10.1007/s11469-015-9553-2

Bulut, İ. (2009). Öğretmen adaylarının öğretmenlik mesleğine ilişkin tutumlarının değerlendirilmesi (Dicle ve Firat üniversitesi örneği). Dicle Üniversitesi Ziya Gökalp Eğitim Fakültesi Dergisi, 14, 13-24.

Camadan, F., \& Duysak, A. (2010). Farklı programlardaki öğretmen adaylarının öğretmenlik mesleğine yönelik tutumlarının çeşitli değişkenler açısından karşılaştırılması: Rize üniversitesi örneği. Sakarya Üniversitesi Eğitim Fakültesi Dergisi, 20, 30-42.

Çayak, S. (2014). İlkokul öğretmenlerinin yapılandırmacı yaklaşımı uygulamaya yönelik tutumları ile özyeterlikleri arasındaki ilişki. Mehmet Akif Ersoy Üniversitesi Eğitim Fakültesi Dergisi, 31, 88-110. 
Çelik, Ö, Yorulmaz, A., \& Çokçalışkan, H. (2019). Öğretmen Genel Yeterlikleri Açısından Sınıf Öğretmenleri ve Öğretmen Adaylarının Kendilerini Değerlendirmeleri. Eskişehir Osmangazi Üniversitesi Sosyal Bilimler Dergisi, 20, 203-215. https://doi.org/10.17494/ogusbd.548342

Demirtaş, H., \& Kırbaç, M. (2016). The views of Pedagogic Formation Certificate Program Students Regarding Pedagogic Formation Training. Trakya University Journal of Education Faculty, 6(2), 138-152.

Dönmez, C., \& Tangülü, Z. (2012). Türkiye Cumhuriyeti İnkılâp Tarihi ve Atatürkçülük dersinde öğretmenlerin gazete kullanımına ilişkin tutumlarının çeşitli değişkenlere göre incelenmesi. Gazi Üniversitesi Gazi Ĕ̆itim Fakültesi Dergisi, 32(2), 347-361.

Dönmez, C., \& Uslu, S. (2013). Sosyal bilgiler öğretmen adaylarının öğretmenlik mesleğine yönelik tutumları. Türk Ĕ̈itim Bilimleri Dergisi, 11(1), 42-63. https://doi.org/10.23863/kalem.2017.18

Dündar, H., \& Karaca, E. T. (2013). Formasyon öğrencilerinin 'pedagojik formasyon programına ilişkin sahip oldukları metaforlar. Gazi Üniversitesi Endüstriyel Sanatlar Eğitim Fakültesi Dergisi, 30, 19-34.

Durmaz, A., \& Kiriş-Avaroğulları, A. (2016). Sosyal bilgiler derslerinde etkinlik uygulamalarının öğrenci motivasyonuna etkisi. Turkish Studies, 11(3), 995-1010. https://doi.org/10.7827/TurkishStudies.9409

George, D., \& Mallery, M. (2003). SPSS for Windows Step by Step: A Simple Guide and Reference 11.0 update. Boston: Pearson.

Göçer, S. (2019). Öğretmen Adaylarının Gelecek Öğretmenlik Performansına İlişkin Beklenen ve Korkulan Olası Benlikleri. Kastamonu Eğitim Dergisi, 27(5), 1841-1864. https://doi.org/10.24106/kefdergi.2777

Gökçe, F., \& Sezer, G. O (2012). Öğretmen Adaylarının Öğretmenlik Mesleğine Yönelik Tutumları (Uludağ Üniversitesi Örneği). Uludağ Ĕgitim Fakültesi Dergisi, 25(1), 1-23.

Gökdemir, A., \& Gazel, A. A. (2019). Ters yüz öğrenmenin sosyal bilgiler öğretmen adaylarının yapılandırmacılığa yönelik tutumlarına etkisi. Eğitim Kuram ve Uygulama Araştırmaları Dergisi, 5(2), 239-249.

Hamman, D., Wang, E., \& Burley, H. (2013). What I expect and fear next year: Measuring new teachers' possible selves. Journal of Education for Teaching, 39(2), 222-234. https://doi.org/10.1080/02607476.2013.765194

Kahramanoğlu, R., Yokuş, E., Cücük, E., Vural, S., \& Şiraz, F. (2018) öğretmenlik mesleğine yönelik tutum ölçeği (ÖMYTÖ) geçerlik ve güvenirlik çalışması. Turkish Studies Educational Sciences, 13(11), 1669-1686. https://doi.org/10.7827/TurkishStudies.13561

Karalı, M. A. (2018). Sosyal bilgiler ögretmen adaylarının meslek öncesi öğretmen kimlik düzeyleri ile olası benlikleri arasindaki iliş̧kinin incelenmesi (Unpublished master's dissertation). Uşak Üniversitesi, Sosyal Bilimler Enstitüsü Uşak

Karatekin, K., Merey, Z., \& Keçe, M. (2015). Sosyal Bilgiler Öğretmen Adaylarının Öğretmenlik Mesleğine Yönelik Tutumları. YYÜ Eğitim Fakültesi Dergisi (YYU Journal of Education Faculty), 12(1), 70-96.

Kartal, T., \& Afacan, Ö. (2012). Pedagojik formasyon eğitimi alan öğretmen adaylarının öğretmenlik mesleğine ilişkin tutumlarının incelenmesi. Mehmet Akif Ersoy Üniversitesi Eğitim Fakültesi Dergisi, 12(24), 76-96.

Kaya, M. (1997). Ailede Anne-Baba Tutumlarının Çocuğun Kişilik ve Benlik Gelişimindeki Rolü. Ondokuz Mayls Üniversitesi İlahiyat Fakültesi Dergisi, 9(9), 193-204.

Kiriş-Avaroğulları, A., \& Vurgun, A. (2018). Analysis of Historical Questions of History Teachers, History Teacher Candidates and High School Students. Kastamonu Education Journal, 26(1), 135-142.

Markus, H., \& Nurius, P. (1986). Possible Selves. American Psychologist, 41(9), 954-969. https://doi.org/10.1037/0003-066X.41.9.954

Özdemir, M., Tulumcu, F. M., \& Tulumcu, F. I. (2019). Türkçe ve Türk dili ve edebiyatı öğretmen adaylarının öğretmenlik mesleğine yönelik algıları. Ana Dili Eğitimi Dergisi, 7(2), 285-302. https://doi.org/10.16916/aded.485425

Sever, D., Aktaş, B., Şahin, S., \& Tunca, N. (2015). Problems that Pedagogical Formation Certificate Program Students Think that They will Encounter in Their Professional Lives Pedagojik Formasyon Sertifika Programı Öğrencilerinin Öğretmenlik Mesleğine Başladıklarında Karşılaşabileceklerini düşündükleri sorunlar. Anadolu Journal of Educational Sciences International, 5(2), 1-23. https://doi.org/10.18039/ajesi.35496 
Tatl1-Dalioğlu, S. (2016). Öğretmen adaylarının meslekteki ilk yıllarına yönelik olası benlikleri ile öz-yeterlik inançları ve ögretmenliğe ilişkin tutumları arasındaki ilişki (Yayımlanmamış doktora tezi). Anadolu Üniversitesi, Eğitim Bilimleri Enstitüsü. Eskişehir. https://doi.org/10.17860/mersinefd.336737

Tatl1-Dalioğlu, S., \& Adıgüzel, O. (2015). “Öğretmen Adaylari Olasi Benlikler Ölçeği”ni Türkçe’ye Uyarlama Çalişmasi. Elektronik Sosyal Bilimler Dergisi, 14(53), 173-185. https://doi.org/10.17755/esosder.42110

Tatlı-Dalioğlu, S., \& Adıgüzel, O. (2017). The Relationship between Teacher Candidates' Possible Selves, Self-Efficacy Beliefs and Attitudes towards Teaching. Mersin Üniversitesi Eğitim Fakültesi Dergisi, 13(2), 173-185. https://doi.org/10.17860/mersinefd.336737

Tavşanlı, Ö. F., \& Saraç, E. (2016). Sınıf Öğretmeni Adaylarının Oluşması Muhtemel Öğretmen Kimliklerinin "Öğretmen Adayları Olası Benlikler Ölçeği” Kullanılarak İncelenmesi. The Journal of Academic Social Science, 4(36), 689-703. https://doi.org/10.16992/ASOS.11786

Tay, B., \& Akyürek-Tay, B. (2006). Sosyal bilgiler dersine yönelik tutumun başarıya etkisi. Türk Eğitim Bilimleri Dergisi, 4(1), 73-84.

Terzi, A. R., \& Tezci, E. (2007). Necatibey eğitim fakültesi öğrencilerinin öğretmenlik mesleğine ilişkin tutumları. Kuram ve Uygulamada Eğitim Yönetimi, 52, 593-614.

Urbay-Şen, A. (2015). Eğitim Fakültesi Mezunu Olan Öğretmenlerle, Eğitim Fakültesi Mezunu Olmayan Öğretmenlerin Meslek Alglları Farklılaşmakta Mıdır? İstanbul: Yeditepe Üniversitesi, Yüksek lisans tezi.

Uygun, K. (2019). Sosyal bilgiler ve psikoloji-sosyal psikoloji. In İ. H. Demircioğlu, S. Kaymakçı, E. Demircioğlu (Eds.), Türkiye'de Sosyal Bilgiler Eğitimi Araştırmaları El Kitabı (pp. 613-634). Ankara: Pegem Akademi.

Uygun, K., \& Karal1, M. A. (2019). Examination of the relationship between social studies teacher candidates of pre-service teacher identity levels and possible self-esteem levels. Sakarya University Journal of Education, 9(3), 578-590. https://doi.org/10.19126/suje.618224

\section{Copyrights}

Copyright for this article is retained by the author(s), with first publication rights granted to the journal.

This is an open-access article distributed under the terms and conditions of the Creative Commons Attribution license (http://creativecommons.org/licenses/by/4.0/). 